\title{
Effects of Forest Resources on the Reception of Foreign Direct Investment in Congo Basin Countries
}

\author{
Julien Ghislain Mouanda Makonda1,2 \\ ${ }^{1}$ Faculty of Economic Sciences of the University Marien NGOUABI of Brazzaville, Congo \\ ${ }^{2}$ Laboratory of Economic and Social Research and Studies, Brazzaville, Congo \\ Email: julien.mouanda-makonda@umng.cg
}

How to cite this paper: Mouanda Makonda, J. G. (2021). Effects of Forest Resources on the Reception of Foreign Direct Investment in Congo Basin Countries. Theoretical Economics Letters, 11, 125-144. https://doi.org/10.4236/tel.2021.111010

Received: January 8, 2021

Accepted: February 23, 2021

Published: February 26, 2021

Copyright ( 2021 by author(s) and Scientific Research Publishing Inc. This work is licensed under the Creative Commons Attribution International License (CC BY 4.0).

http://creativecommons.org/licenses/by/4.0/ (c) (i) Open Access

\begin{abstract}
The objective of this article is to analyze the effects of forest resources on the reception of foreign direct investment in the countries of the Congo Basin. The panel data used cover the period 1996-2018 and are extracted from the World Bank's WDI and WGI databases. The spatial autocorrelation of FDI inflows into the Congo Basin motivates the use of a Spatial Dynamic Durbin Model (SDM). The results of the estimation of this model by the maximum likelihood method show that forest resources have a significant positive effect on FDI inflows and that the spillover effects of inflows from the neighborhood $(\rho)$ are also positive and significant. These results imply the need for: 1 ) the generalization of logging in forest concessions while encouraging their certification and 2) the subregional harmonization of a repressive mechanism in cases where the legal and regulatory texts regarding logging are violated.
\end{abstract}

\section{Keywords}

Foreign Direct Investment, Forest Resource, Congo Basin

\section{Introduction}

The exploitation of natural resources in general and forestry resources in particular are the main motives for foreign direct investment in developing countries. These countries are characterized by insufficient domestic savings on the one hand and confronted with the imperatives of sustainable development on the other, and the countries of the Congo Basin ${ }^{1}$ are hardly an exception. Indeed,

${ }^{1}$ These are mainly the countries that are geographically part of the Congo Basin (Cameroon, Central African Republic, Congo, Gabon, Equatorial Guinea and the Democratic Republic of Congo). 
this area, which is home to the second largest tropical forest in the world in terms of surface area (approximately 3 million $\mathrm{km}^{2}$ ) after the Amazon (approximately 7.7 million $\mathrm{km}^{2}$ ), is the subject of particular attention from the international community, all the more so because it contributes to the mitigation of greenhouse gas emissions, which are the cause of climate change.

These countries have faced a significant influx of foreign direct investment in recent years, attracted, among other things, by the importance of forest cover and species in the area. By way of illustration, FDI inflows have increased from 5 billion dollars in 2013 to approximately 7.6 billion dollars in 2018, and these have concentrated in two countries: Congo, 4.3 billion or $56.58 \%$, and the Democratic Republic of Congo, 1.3 billion or $16.85 \%$ in $2018^{2}$. At the same time, there has also been an annual loss of forest cover in the area of approximately $4988^{3} \mathrm{~km}^{2}$ between 2015 and 2016. The Democratic Republic of Congo and Cameroon are in the lead for this metric, with losses of $3114 \mathrm{~km}^{2}$ and $2200 \mathrm{~km}^{2}$ respectively.

In the literature, the debate is approached from the perspective of the effects of natural resources on foreign direct investment. On the theoretical level, two opposing groups of theories exist: The first group includes international trade theories and accepts the positive effect of natural resources on FDI inflows. Thus, a country's endowment in raw materials constitutes a specific advantage in mobilizing FDI based on a primary strategy (Dunning, 1993). Similarly, FDI that emphasizes vertical and horizontal integration strategies are attracted to areas that are better endowed with natural resources (Mucchielli, 1991).

The second group, by contrast, supports the negative effect of natural resources on FDI inflows. This group relies on the natural resource curse ${ }^{4}$ hypothesis, which explains this negative effect by: 1) the volatility of commodity prices (van der Ploeg, 2011; Moradbeigi \& Law, 2016); 2) the presence of oligarchic, autocratic or dictatorial institutions (de Soysa, 2002; Fearon, 2005; Robinson, 2014; Kaldor et al., 2007; Botlhole et al., 2012; Wright et al., 2015; Caselli \& Tesei, 2016; Wiig \& Kolstad, 2010); 3) the existence of anarchic institutions with nonapplication of property rights (Beblawi, 1987; Karl, 2007; Auty, 2001; Ross, 2001); 4) the emergence of civil wars (Collier \& Hoeffler, 2002; Ross, 2004; Collier et al., 2009); 5) the existence of Dutch disease (Corden \& Neary, 1982; Krugman, 1987; Papyrakis \& Gerlagh, 2004; Slaibi \& Kyle, 2007); and 6) the absence of long-term planning (Humphreys et al., 2007).

On the empirical level, the studies carried out confirm the controversies noted on the theoretical level. Thus, Asiedu \& Lien (2003) and Onyeiwu \& Shrestha (2004) find in panel data from some African countries a positive relationship between natural resource endowments and FDI inflows. However, Poelhekke and van der Ploeg $(2010,2013)$ conclude from their study of selected African ${ }^{2}$ Author's calculations based on data extracted from WDI and UNCTAD (2019).

${ }^{3}$ Author's calculations based on data extracted from WDI.

${ }^{4}$ Auty and Warhurst (1993) define the natural resource curse, or paradox of abundance, as the perverse effects of a country's natural resource wealth on its economic, social or political well-being. 
countries that natural resource endowments have a negative effect on FDI inflows overall. Taking into account these controversies, the objective of this paper is to analyze the effects of forest resources on the reception of FDI in the countries of the Congo Basin. Two reasons justify the choice of this area: the loss of forest cover in the zone, which raises questions about the regulatory role for the global climate played by this region along with the Amazon, and the imperatives of sustainable development centered essentially on the responsible exploitation of natural resources in general and forest resources in particular. In addition to the introductory section, the remainder of this work is structured in four sections: the second includes the literature review, the third section discusses methodology, the fourth presents and interprets the results, and the fifth section is devoted to the conclusion and policy implications.

\section{Literature Review}

Generally, the two groups of theories clash, and their conclusions are both theoretically and empirically contradictory. At the theoretical level, and with regard to the theories that support the positive effect of natural resources, we distinguish between the theory of production factor endowments (Heckscher, 1919; Ohlin, 1933; Samuelson, 1948), eclectic theory (Dunning, 1979, 1988), product life cycle theory (Vernon, 1966), the theory of firm internalization (Coase, 1988) and the theory of market imperfection (Krugman, 1991). These theories highlight the existence of a country-specific advantage resulting from factor endowments. Thus, in the particular case of the product life cycle, the relocation of firms during the maturity phase generates FDI motivated by the control of raw materials; the challenge for the leading firm is to maintain its technological lead. Similarly, the theory of internalization shows that it is advantageous for a firm to have control over its sources of supply for raw materials. This advantage will result in the deployment of firms to countries endowed with natural resources.

The second group of theories supports the negative effect of natural resource endowments based on the hypothesis of the curse of natural resources (Collier \& Hoeffler, 1998; Auty, 2001; Gylfason \& Zoega, 2006; Asiedu \& Lien, 2011). These authors highlight two factors: the crowding out effect of FDI from the natural resource sector and the political instability, corruption and low investment in physical and human capital generated by a country's natural resource endowment. With respect to crowding out, increased FDI in the natural resource sector can, like Dutch disease, discourage investment in other sectors, which can lead to a net decline in FDI in the economy as a whole. With regard to the second factor, political instability and corruption generated by the exploitation of natural resources hamper investment in non-extractive sectors.

For the empirical review, the results obtained are mixed insofar as the controversies observed at the theoretical level are also noted. Thus, Morisset (2000), in an econometric study of 29 Sub-Saharan African countries for the period 1990-1997 using panel and cross-sectional data, finds that the availability of natural re- 
sources has a positive effect on FDI inflows, with elasticities of 0.92 and 1.2, respectively.

Noorbakhsh et al. (2001), Asiedu (2002, 2006), Onyeiwu and Shrestha (2004), Anyanwu (2012) and Jadhav (2012), in their respective studies, conclude that resource-rich countries receive more FDI than resource-poor countries, the majority of these resources being oriented towards the extractive sector.

Similar to Cleeve et al. (2015), Mensah and Asamoah (2015), in their studies of 35 and 49 Sub-Saharan African countries during the periods 1980-2012 and 1980-2011, respectively, conclude that there is a positive relationship between natural resources and FDI inflows.

However, Asiedu \& Lien (2003), in a study of panel data from 22 African countries for the period 1984-2000, puts this conclusion into perspective by arguing that FDI inflows into Africa are not solely motivated by its natural resource endowment and condition the positive effect of natural resources on the existence of a stable macroeconomic framework, political stability, good infrastructure and an effective legal framework in the host country.

Soysa and Neumayer (2007), in their study on the effect of natural resources on FDI inflows in selected developing countries, conclude that natural resources captured by forestry, mining and oil rents have a negative effect on FDI inflows. The main explanation is that these natural resources are the origin of ethnic conflicts and civil wars that alter the stability of the business climate essential for attracting FDI flows directed towards the industrial and services sectors. In this vein, Asiedu (2013), in his work on selected Sub-Saharan African countries, finds a negative relationship between a country's natural resources and its FDI inflows. The explanation she gives for this is the curse of natural resources, which generates an unstable environment less favorable to foreign direct investment.

These contradictory results for the nature of the effect of natural resources on FDI inflows lead us to deepen our reflection in the Congo Basin, which is subject to a double imperative: the sustainable development of member countries and ensuring, alongside the Amazon, the regulation of the global climate.

\section{Methodology}

This analysis is structured in six points: the theoretical framework and specification of the model, the presentation of the model variables, the nature of the panel and the spatial autocorrelation test, the stationarity and cointegration of the variables, the stylized facts and the descriptive statistics.

\subsection{Theoretical Framework and Model Specification}

The factors explaining FDI inflows in the literature fall into two broad categories: micro and macroeconomic factors. Generally, according to Kinda (2010), the decision to invest in a foreign country depends fundamentally on the expected return on investment or the profit expected from such investment. Profit ( $\Pi)$ is the difference between total revenue (TR) and total cost (TC). The func- 
tional form is:

$$
\Pi=f(P, Q, T C),
$$

With $T C=I C+O C+H C ; \mathrm{d} \Pi / \mathrm{dP}, \mathrm{d} \Pi / \mathrm{dQ}>0$ et $\mathrm{d} \Pi / \mathrm{dIC}, \mathrm{d} \Pi / \mathrm{dOC}, \mathrm{d} \Pi / \mathrm{dHC}$ $<0$.

$\mathrm{P}=$ output price $(Q)$ determined by the market; $T C=$ total cost; $I C=$ input cost (cost of labor, land, raw materials, etc.);

$O C=$ operating costs (financial costs, time costs, transaction and transportation costs); $H C=$ hidden cost (difference between the time and money costs reported by the government and the time and money actually paid by the investor). The variables that determine profit also determine the inflow of FDI into a country; hence, the reduced form:

$$
\begin{gathered}
F D I=f(P, Q, T C) \\
F D I_{i t}=f(P, Q, I C, O C, H C)
\end{gathered}
$$

Taking into account the review of the literature, we retain the following explanatory variables: forest rent (FR), gross domestic product per capita (GDP_H), degree of openness (DO), FDI lagged by one period (FDI $(-1)$ ), corruption control (CC) and gross fixed capital formation (GFCF). The implicit form of the model is FDI $=f\left(\mathrm{FR}, \mathrm{GDP} \_\mathrm{H}, \mathrm{DO}, \mathrm{FDI}(-1), \mathrm{CC}, \mathrm{GFCF}\right)$. The explicit formulation in panel data is as follows:

$$
\begin{aligned}
F D I_{i t}= & \beta_{0}+\beta_{1} F R_{i t}+\beta_{2} G D P_{-} H_{i t}+\beta_{3} D O_{i t} \\
& +\beta_{4} F D I(-1)_{i t}+\beta_{5} C C_{i t}+G F C F_{i t}+\varepsilon_{i t}
\end{aligned}
$$

\subsection{Presentation of Variables}

We next distinguish the explained and the explanatory variables.

\subsubsection{Explained Variable}

FDI: Foreign direct investment. It represents net FDI inflows as a percentage of gross domestic product. It also captures the importance of foreign financial flows in relation to domestic production.

\subsubsection{Explanatory Variables}

A distinction is made between the variable of interest and the control variables.

\section{1) Variable of interest}

FR: Forest annuity. It represents the resources from logging activities. It is also expressed as a percentage of GDP. The expected sign is ambiguous $\left(\beta_{1}<0\right.$ or $\left.\beta_{2}>0\right)$

\section{2) Control variables}

GDP_H: Gross domestic product per capita. It reflects the purchasing power of the population and represents the size of the market. According to the literature, the expected sign is positive $\left(\beta_{2}>0\right)$;

DO: Degree of openness. It represents the degree of openness of the economy. It is the sum of exports and imports relative to GDP. It is expressed as a percentage. A high degree of openness attracts investors because they can easily import 
capital goods and sell their products. The expected sign of this variable is positive $\left(\beta_{3}>0\right)$;

FDI (-1): Foreign direct investment lagged one period. It reflects the influence that the previous year's FDI has on the current year's FDI. Indeed, the existence of FDI in a country reassures investors who wish to settle there by suggesting opportunities exist for partnerships, the exchange of information, etc. The expected sign of this variable is positive $\left(\beta_{4}>0\right)$;

CC: Control of corruption. It reflects the quality of governance in the host country. The more effective the control is, the greater the flow of inward FDI because it does not mix well with corruption. According to the literature, the expected sign is positive $\left(\beta_{5}>0\right)$, and $\varepsilon_{i t}$ is the error term;

GFCF: Gross fixed capital formation (as a percentage of GDP). This variable is taken into account to reflect the effects of complementarity between foreign and domestic capital. The expected sign is not determined a priori $\left(\beta_{6}<0\right.$ or $\left.\beta_{6}>0\right)$.

\subsection{Nature of the Panel and Spatial Autocorrelation Test}

The use of panel data requires clarification on the nature (homogeneous or heterogeneous) of the panel and on whether the spatial dimension is taken into account in the analysis.

\subsubsection{Nature of the Panel}

Data exploration is performed in the first step, and in the second step, a statistical test is conducted.

\section{1) Data mining}

Data mining graphically assesses the nature of the panel on individual and temporal dimensions as shown in the two Figure 1 \& Figure 2 below.

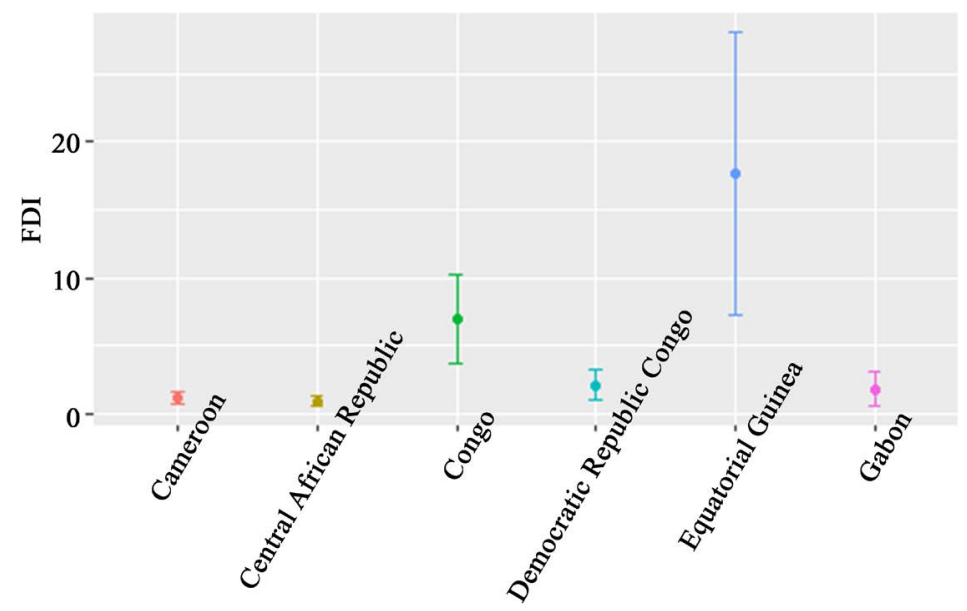

Figure 1. Individual dimension.

These Figures show that the confidence interval of average FDI inflows is variable in both dimensions. This double variability suggests possible heterogeneity in the Congo Basin. 


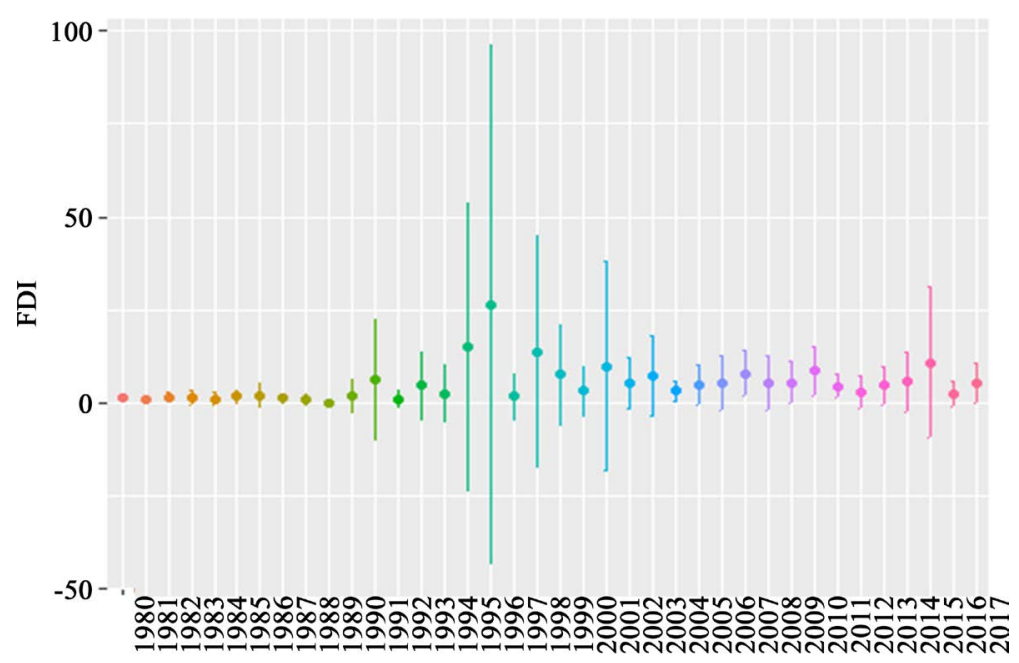

Source: Author, extracted from WDI World Bank (2019) data.

Figure 2. Temporal dimension.

\section{2) Specification test}

The results of the Hsiao (1986) test are summarized in Table 1 below.

Table 1. Test results for the Congo Basin.

\begin{tabular}{|c|c|c|c|c|}
\hline \multicolumn{3}{|c|}{ Different stages of the test } & \multirow{2}{*}{ Nature panel } & \multirow{2}{*}{ Specification } \\
\hline Hypothesis & Stat. Fisher & $\mathrm{P}$-value & & \\
\hline$H_{0}^{1}: \alpha_{i}=\alpha \beta_{i}=\beta \quad \forall i$ & $F_{1}=9.7817$ & $P_{1}=6.251 e-18$ & \multirow{3}{*}{$\begin{array}{c}\text { Partially } \\
\text { homogeneous }\end{array}$} & \multirow{3}{*}{$\begin{array}{c}Y_{i t}=\alpha_{i}+X_{i t} \beta+\varepsilon_{i t} \\
\text { Effect model } \\
\text { individual }\end{array}$} \\
\hline$H_{0}^{2}: \beta_{i}=\beta$ & $\mathrm{F}_{2}=3.3276$ & $\mathrm{P}_{2}=0.0863$ & & \\
\hline$H_{0}^{3}: \alpha_{i}=\alpha$ & $\mathrm{F}_{3}=26.1039$ & $\mathrm{P}_{3}=4.214 \mathrm{e}-18$ & & \\
\hline
\end{tabular}

Source: Author, based on results obtained from Stata 15.

The results of the test show that, with a 5\% risk of error, the panel comprising the countries of the Congo Basin is partially homogeneous. Therefore, an individual effects model will be estimated.

\subsubsection{Spatial Autocorrelation Test}

This work concerns an area characterized by two types of proximity: geographical proximity (some countries share the same border) and institutional proximity (these countries are signatories to international agreements on sustainable forest management). In view of geographical proximity, it cannot be ruled out that for a company with activities in two neighboring countries, the level of investment in one country may be correlated with that of its neighbor. In such a case, it is reasonable to assume the existence of spatial dependence (spatial interaction) in a variable from one country to another. The use of a spatial model is subject to the existence of spatial autocorrelation in the dependent variable; spatial autocorrelation designating the absence of independence between neighboring observations. This lack of independence is stronger when the locations are 
closer (Tobler, 1970). The objective of the test is to evaluate the spatial dependence of FDI inflows into the Congo Basin. The results of the three tests are shown in Table 2 below.

Table 2. Spatial autocorrelation test results.

\begin{tabular}{cccccc}
\hline Different tests & Index value & Esperance & Ecart-type & Statistics & P-value \\
\hline Moran (I) & $\mathrm{I}=-0.034$ & $\mathrm{E}(\mathrm{I})=-0.007$ & $\mathrm{Sd}(\mathrm{I})=0.004$ & $\mathrm{z}=-7.531$ & 0.000 \\
Geary $(\mathrm{C})$ & $\mathrm{C}=1.026$ & $\mathrm{E}(\mathrm{C})=1$ & $\mathrm{Sd}(\mathrm{C})=0.004$ & $\mathrm{z}=7.531$ & 0.000 \\
Getis \& Ord (G) & $\mathrm{G}=0.697$ & $\mathrm{E}(\mathrm{G})=0.839$ & $\mathrm{Sd}(\mathrm{G})=0.019$ & $\mathrm{z}=-7.531$ & 0.000 \\
\hline
\end{tabular}

Source: Author, based on estimates from Stata 15.

The null hypothesis is the absence of spatial autocorrelation. The three indices and the P-values (less than 5\%) reveal the existence of negative spatial autocorrelation in FDI inflows into the Congo Basin. A spatial model ${ }^{5}$ should be considered, but confirmation requires a test of non-nullity of the parameters $\rho$ and/or $\lambda$ carried out on the residuals of the stacked model obtained by the ordinary least squares method. The results of this test are summarized in Table 3 below.

Table 3. Test results.

\begin{tabular}{cccc}
\hline Types of interaction & Different tests & Statistics & P-Value \\
\hline Spatial Error $(\lambda)$ & Lagrange multiplier & 13.03 & 0.000 \\
& Robust Lagrange Multiplier & 52.63 & 0.000 \\
\hline Décalage spatial $(\rho)$ & Lagrange multiplier & 0.193 & 0.660 \\
& Robust Lagrange Multiplier & 39.793 & 0.000 \\
\hline
\end{tabular}

Source: Author, based on estimates from Stata 15

The results show that the null hypothesis ( $\rho=0, \lambda=0$ reflecting the absence of spatial dependence of FDI inflows) is rejected because the P-values for the Lagrange robust multiplier test are lower than the $5 \%$ error risk. Therefore, the parameters $\rho$ and $\lambda$ are significantly different from zero. In this case, the spatial model to be estimated is the most robust model, the SDM (Elhorst, 2010; Le Gallo, 2004). Thus, the effect of forest resources on FDI inflows into the Congo Basin will be estimated by a spatial model, the SDM, whose vector form is:

$$
y=\rho w y+x \beta+w x \theta+\mu+\varepsilon
$$

$\mathrm{y}$ is the FDI inflows; $\mathrm{x}$ is the explanatory variables; $\mu$ represents individual effects; $\varepsilon$ is the error term; $\rho$ is the degree of dependence of a country's FDI inflows on those of its neighbors; $\beta$ is the estimators reflecting the effect of a country's explanatory variables on its FDI inflows; $\theta$ is the estimators reflecting the effect

${ }^{5}$ The main models in vector form are: the spatial Durbin model SDM $(y=\rho w y+x \beta+w x \theta+\mu+\varepsilon)$, the spatial error model SEM $(y=x \beta+\mu+v ; v=\lambda w v+\varepsilon)$; the spatial autoregressive model SAR $(y=\rho w y+x \beta+\mu+\varepsilon)$; $\rho$ et $\lambda$ measure the degree of dependence of the variable, and $w$ the weight matrix used. 
of explanatory variables from neighboring countries on a country's FDI inflows; and $\mathrm{w}$ is the weight matrix ${ }^{6}$ that captures the effect of space in explaining FDI inflows. Since individual effects can be fixed or random, the Hausman test is applied and yields the following results (Table 4).

Table 4. Hausman test results.

\begin{tabular}{ccc}
\hline Chi-square statistics & Degree of freedom & P-value \\
\hline 380.93 & 4 & $2.2 \mathrm{e}-16$ \\
\hline
\end{tabular}

Source: Author, based on estimates from Stata 15.

Since the P-value is lower than the maximum risk of error (5\%), the fixed-effects model is appropriate.

\subsection{Stationarity and Cointegration of Variables}

\subsubsection{Stationarity}

The results at the $5 \%$ threshold are summarized in Table 5 below.

Table 5. Results of the different tests.

\begin{tabular}{ccccccc}
\hline & \multicolumn{2}{c}{ LLC } & & \multicolumn{2}{c}{ IPS } & \multicolumn{2}{c}{ Hadri } \\
\hline \multirow{2}{*}{ Variables } & Level & Difference & Level & Difference & Level & Difference \\
\cline { 2 - 7 } & Model 3 & Model 2 & Model 3 & Model 2 & Modèle 3 & Model 2 \\
\hline FDI & -0.3687 & $-11.73^{* * *}$ & $-5.8911^{* * *}$ & - & 3.1459 & $-0.4782^{* *}$ \\
FR & $-3.1834^{* * *}$ & - & $-3.6678^{* * *}$ & - & 9.2950 & $-0.7521^{* *}$ \\
GDPH & -1.6368 & $-1.7130^{* *}$ & -0.9576 & $-2.0829^{* *}$ & 25.7517 & $2.541^{* * *}$ \\
DO & 0.8039 & $-12.4917^{* *}$ & $-3.7202^{* * *}$ & $-7.7941^{* *}$ & 3.1612 & $0.2582^{* *}$ \\
CC & $-2.5846^{* *}$ & - & $-1.9881^{* *}$ & - & 6.6229 & $-1.0201^{* *}$ \\
GFCF & -0.4613 & $-10.3718^{*}$ & $-2.9377^{* *}$ & - & 4.9252 & $-1.4060^{* *}$ \\
\hline
\end{tabular}

Source: Author, based on estimates from Stata 15.

According to these results, the variables FDI, GDPH, DO and GFCF are stationary in first difference (integrated of order 1), and the variables FR and CC are stationary in level (integrated of order 0 ).

\subsubsection{Cointegration}

Because the panel is partially heterogeneous, we use the Pedroni (2001) test, which takes heterogeneity into account through parameters that may be different from one individual to another. The results of the test are as follows (Table 6).

These results show that the variables in the model have a long-term relationship in both dimensions because most of the statistics are significantly different from zero at the $1 \%$ threshold.

${ }^{6}$ The proximity taken into account here is the importance of the forest cover of two countries in the entire Congo Basin. Thus, the elements of this matrix represent the inverse of the importance of the forest cover of the two countries, except for the main diagonal, which by convention is nil. 
Table 6. Pedroni cointegration test results.

\begin{tabular}{|c|c|c|c|c|c|}
\hline \multirow{3}{*}{ Panel } & \multicolumn{5}{|c|}{ With intercept and trend Without intercept and trend } \\
\hline & & Statistics & Probability & Statistics & Probability \\
\hline & & \multicolumn{2}{|c|}{ Within } & \multicolumn{2}{|c|}{ Within } \\
\hline & Panel v- & 0.6848 & 0.2467 & $3.8970^{* * *}$ & 0.0000 \\
\hline & Panel rho & $-4.8946^{* * *}$ & 0.0000 & $-4.7918^{* * *}$ & 0.0000 \\
\hline & Panel PP & $-8.9785^{\star * *}$ & 0.0000 & $-5.2410^{* * *}$ & 0.0000 \\
\hline Congo & Panel ADF & $-8.5190^{* * *}$ & 0.0000 & $-5.7548^{\star * *}$ & 0.0000 \\
\hline \multirow[t]{4}{*}{ Basin } & & Between & & \multicolumn{2}{|c|}{ Between } \\
\hline & Group rho & $-3.5324^{* * *}$ & 0.0002 & $-4.6300^{* * *}$ & 0.0000 \\
\hline & Group PP & $-3.5324^{* * *}$ & 0.0000 & $-7.7074^{* * *}$ & 0.0000 \\
\hline & Group ADF & $-10.1237^{\star * *}$ & 0.0000 & $-8.7007^{* * *}$ & 0.0000 \\
\hline
\end{tabular}

Source: Author, based on estimates from Stata 15.

\subsection{Descriptive Statistics (Table 7)}

Table 7. Descriptive statistics of the Congo Basin.

\begin{tabular}{|c|c|c|c|c|c|c|c|}
\hline Dimensions & & FDI & FR & GDPH & DO & $\mathrm{CC}$ & GFCF \\
\hline \multirow{4}{*}{ Overall } & Min & -8.5894 & 0.3363 & 276.0559 & 25.0419 & -1.8257 & 2.1 \\
\hline & Mean & 6.8419 & 7.6422 & 4516.367 & 84.0491 & -1.2033 & 22.2708 \\
\hline & $\sigma$ & 16.9815 & 7.2416 & 5398.629 & 42.2231 & 0.2678 & 9.8657 \\
\hline & Max & 161.8237 & 33.8025 & 20512.94 & 282.5441 & -0.5907 & 53.6127 \\
\hline \multirow{4}{*}{ Between } & Min & 1.340343 & 3.1510 & 340.6407 & 40.8638 & -1.5475 & 11.3191 \\
\hline & Mean & - & - & - & - & - & - \\
\hline & $\sigma$ & 7.627603 & 6.9107 & 5329.988 & 41.6297 & 0.2554 & 8.2183 \\
\hline & $\operatorname{Max}$ & 20.6942 & 20.1924 & 12652.31 & 140.7364 & -0.8267 & 33.8204 \\
\hline \multirow{4}{*}{ Within } & Min & -17.8718 & -5.9811 & -6714.96 & 49.5077 & -1.4931 & -1.3052 \\
\hline & Mean & - & - & - & - & - & - \\
\hline & $\sigma$ & 15.47694 & 3.5144 & 2301.828 & 18.1122 & 0.1302 & 6.3747 \\
\hline & $\operatorname{Max}$ & 147.9715 & 25.8392 & 12377 & 239.6791 & -0.9201 & 42.0631 \\
\hline
\end{tabular}

Source: Author, extracted from World Bank (WDI and WGI) and UNCTAD databases.

During the period under review (Table 7), FDI inflows into the Congo Basin represented on average $6.84 \%$ of the gross domestic product of the zone, with maximum and minimum values of $161.8 \%$ and $-8.7 \%$, respectively recorded in Equatorial Guinea and Gabon in 1996. There is high variability in these flows, estimated at $248.19 \%$. The major investments made in Equatorial Guinea in the oil sector in 1996 and the effects of socio-political unrest following the democratic exercise in Gabon in the 1990s are the main explanations. In addition, inter- and intra-individual differences are on the order of $7.62 \%$ and $15.47 \%$, respectively. 
Forest rent represents, on average, $7.64 \%$ of the gross domestic product, with a minimum value of $0.33 \%$ recorded in Equatorial Guinea in 2011 and a maximum value of $33.8 \%$ recorded in the DRC in 1996. This configuration can be explained, as far as Equatorial Guinea is concerned, by the massive influx of FDI in the oil sector following the discovery of new deposits, which has led to the decline in FDI in the timber sector. For the DRC, this large share in forest rent is caused by the weakness of legal and regulatory mechanisms for logging. In addition, the control variables are more stable ${ }^{7}$ (low variability).

\subsection{Stylized Facts}

These facts relate to the evolution of FDI inflows and forest rent in the Congo Basin, as shown in Figure 3 \& Figure 4 below.

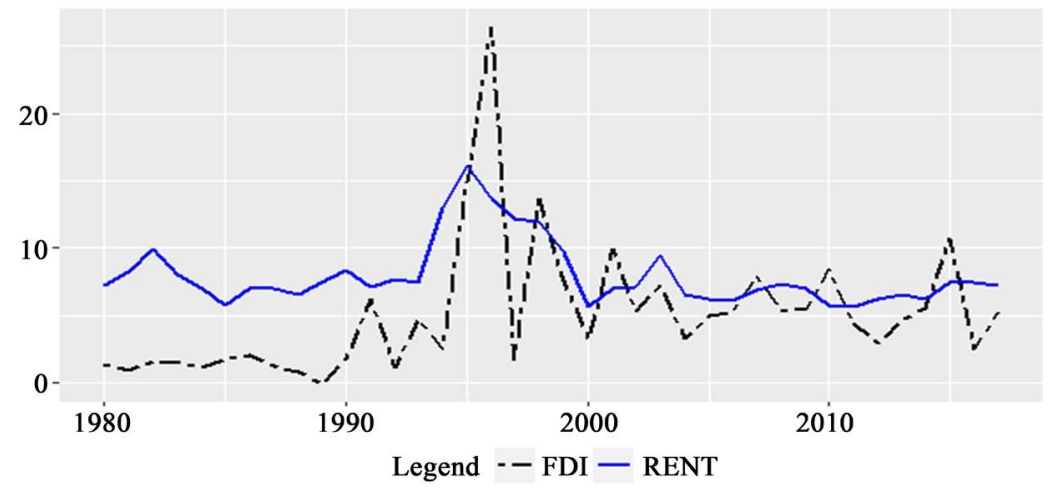

Source: Author, extracted from the World Bank's WDI database.

Figure 3. Evolution of average FDI inflows and forest rent in the Congo Basin (as a percentage of GDP).

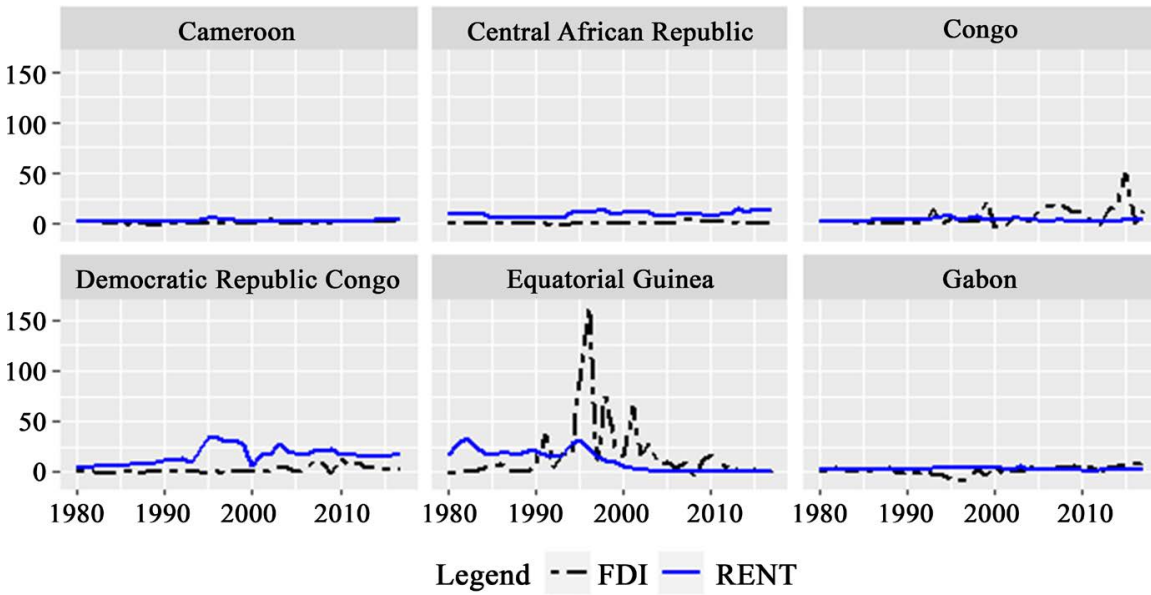

Source: Author, extracted from the World Bank's WDI database

Figure 4. Evolution of FDI inflows and forest rent by country (as a percentage of GDP).

The evolution of FDI inflows and forest rent in the Congo Basin (Figure 3)

${ }^{7}$ Indeed, these variables have a coefficient of variation of less than $100 \%$ with the exception of the GDPH. 
can be analyzed by distinguishing two periods: the first (1980-1995) is marked by an upward trend in both variables that can be explained by the fact that the nature conservation system was still in its infancy. The second period (1995-2017), on the other hand, is characterized by a downward trend in FDI inflows, while the forest rent has a downward trend up to 2000 before evolving in a stable manner after 2000.

The commitments made by member countries with regard to forestry exploitation and the strengthening of the nature conservation system may be the main cause of this trend. Moreover, the peak observed in 1995 is due, as far as FDI inflows are concerned, to their increase in Equatorial Guinea; while that of forest rent originates in the increases recorded in Equatorial Guinea, DRC and Central Africa (Figure 4). In sum, these Figures highlight, both in the basin as a whole and in each country, a link between FDI inflows and forest rent.

\section{Presentation and Interpretation of Results}

The estimation of Durbin's dynamic spatial model (SDM) by the maximum likelihood method gives the following results (Table 8).

\subsection{Presentation of Results}

Table 8. Estimation results for the three dynamic model options.

\begin{tabular}{ccccc}
\hline variables & Model SDM & Model SDM 1 & Model SDM 2 & Model SDM 3 \\
\hline X & & & & \\
FDIL1. & - & $-0.1422^{* * *}$ & - & 0.1220 \\
WFDIL1. & - & - & $0.3643^{* * *}$ & 0.5965 \\
GDPH & -0.0056 & -0.0042 & -0.0040 & -0.0037 \\
DO & -0.0634 & 0.0259 & 0.0059 & -0.0085 \\
FR & 0.6250 & $1.4063^{* * *}$ & $1.3664^{* * *}$ & $1.4070^{* * *}$ \\
CC & $-1.5854^{* *}$ & $-1.3135^{* *}$ & $-1.2210^{* *}$ & -1.3665 \\
GFCF & 0.2518 & 0.3128 & $0.3270^{*}$ & -0.7474 \\
WX & & & & \\
GDPH & -0.0046 & -0.0005 & $-3.51 \mathrm{e}-06$ & 0.0006 \\
DO & $-1.5719^{* * *}$ & 0.0262 & -0.0596 & -0.0950 \\
FR & $6.6771^{* *}$ & $10.3978^{* * *}$ & $9.8190^{* * *}$ & $9.9402^{* * *}$ \\
CC & $-6.0380^{*}$ & $-4.653^{* * *}$ & $-3.9201^{* * *}$ & $-5.9779^{* * *}$ \\
GFCF & 0.5764 & -0.8154 & -0.7545 & -0.7474 \\
$\rho$ & -0.2138 & $0.3463^{* *}$ & $0.2934^{* *}$ & $0.2777^{*}$ \\
$\mathrm{R}^{2}$ within & 0.6372 & 0.5747 & 0.7530 & 0.5401 \\
$\mathrm{R}^{2}$ between & 0.4304 & 0.4977 & 0.5484 & 0.5688 \\
$\mathrm{R}^{2}$ overall & 0.5246 & 0.5021 & 0.6001 & 0.6100 \\
ET_CT & & & & \\
\hline & & & & \\
\hline & & & & \\
\hline & & & & \\
\hline & & & & \\
\hline
\end{tabular}




\begin{tabular}{|c|c|c|c|c|}
\hline Continued & & & & \\
\hline GDPH & - & -0.0037 & -0.0034 & -0.0018 \\
\hline DO & - & 0.0588 & -0.0258 & -0.0701 \\
\hline FR & - & $8.9994^{\star * \star}$ & $8.8936^{* * *}$ & $9.0440^{* * *}$ \\
\hline $\mathrm{CC}$ & - & $-2.2143^{\star * *}$ & $-1.1252^{\star * \star}$ & $-4.7496^{\star * *}$ \\
\hline GFCF & - & -0.4070 & -0.3617 & -0.3438 \\
\hline ET_LT & & & & \\
\hline GDPH & - & -0.0034 & -0.0047 & -0.0043 \\
\hline DO & - & 0.0528 & -0.0359 & -0.1868 \\
\hline FR & - & $8.1083^{\star * *}$ & $12.6587^{* * *}$ & $22.3543^{*}$ \\
\hline $\mathrm{CC}$ & - & $-3.0812^{* * *}$ & $-4.6033^{\star * *}$ & $-2.1796^{*}$ \\
\hline GFCF & - & -0.3656207 & -0.5211 & -0.8576 \\
\hline AIC & 945.829 & 854.5286 & 849.0721 & 850.8658 \\
\hline
\end{tabular}

Source: Author, based on estimates from Stata $15 .\left(^{* * *}\right)$ significant at $1 \%,\left({ }^{* *}\right)$ significant at $\left.5 \%,{ }^{*}\right)$ significant at 10\%. ET_CT, total short-term effect; ET_LT, total long-term effect.

These results show that the SDM2 model minimizes the loss of information because it has a smaller AIC. Therefore, our analysis is based on the results of this model. On the whole, the results are statistically satisfactory because more than $50 \%$ of the variability in FDI inflows into the Congo Basin is explained by the explanatory variables retained in general and by forest resources in particular. Moreover, the spatial interaction coefficient $(\rho)$ of FDI inflows in this zone is positive and statistically significant at the $5 \%$ threshold. Forest resources also have a positive and significant effect at the $1 \%$ threshold on FDI inflows, and these effects are positive and significant in the short and long term. These results are consistent with those of Morisset (2000), Noorbakhsh et al (2001), Asiedu (2002), Onyeiwu and Shrestha (2004), Anyanwu (2012), Jadhav (2012), Cleeve et al (2015), Mensah and Asamoah (2015). Conversely, these results are not in line with those of Asiedu \& Lien (2003), who condition this positive effect on the existence of a stable macroeconomic framework in the host country, or Soysa and Neumayer (2007) and Asiedu (2013), who find a negative effect of natural resources on FDI inflows.

\subsection{Interpretation of Results}

Two arguments can explain the attractiveness of the forest resources of the Congo Basin area to foreign direct investment: the state of forest governance characterized by noncompliance with the legal and regulatory provisions governing forest concessions and the embryonic level of the forestry industry.

With regard to the first argument, the state of forest governance, which can be understood as a product of the level of corruption in the area, plays a major role. In fact, a deterioration in the corruption control index (Kaufman et al., 2012) can be observed, as shown in Figure 5 below. 


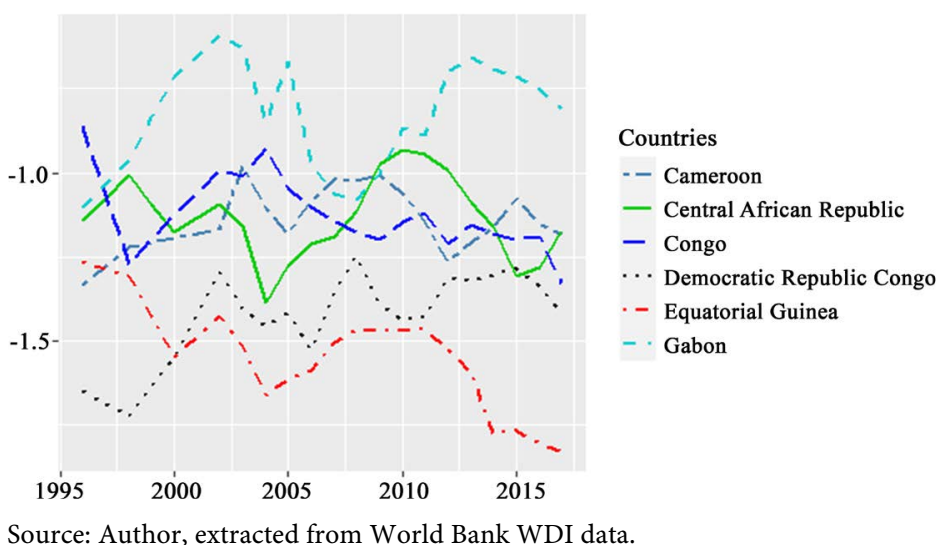

Figure 5. Evolution of the corruption control index in the Congo Basin.

This Figure shows that for the area as a whole and during the period under review, the corruption control index is negative for all countries. Moreover, this index has been steadily deteriorating since 2011. The DRC, which has the largest forest cover in the zone, ranks last with Equatorial Guinea in terms of corruption control. This reflects the scale of governance problems in general and of forest governance in particular in the Congo Basin. Indeed, the extent of corruption in the forest administration of the various countries could be at the root of noncompliance with the provisions of the various forestry codes, in particular provision $85 / 15^{8}$. Violation of this provision in most countries may explain the influx of FDI into the forestry sector, all the more so as companies operating in the sector, mostly of Asian origin, find an opportunity to export their products to international markets considered more remunerative.

For the second argument relating to the embryonic level of the forestry industry, this is reflected in the massive export of logs, the essential consequences of which are the decrease in forest cover and the increase in greenhouse ${ }^{9}$ gas emissions, as seen in Figure 6 \& Figure 7 below.

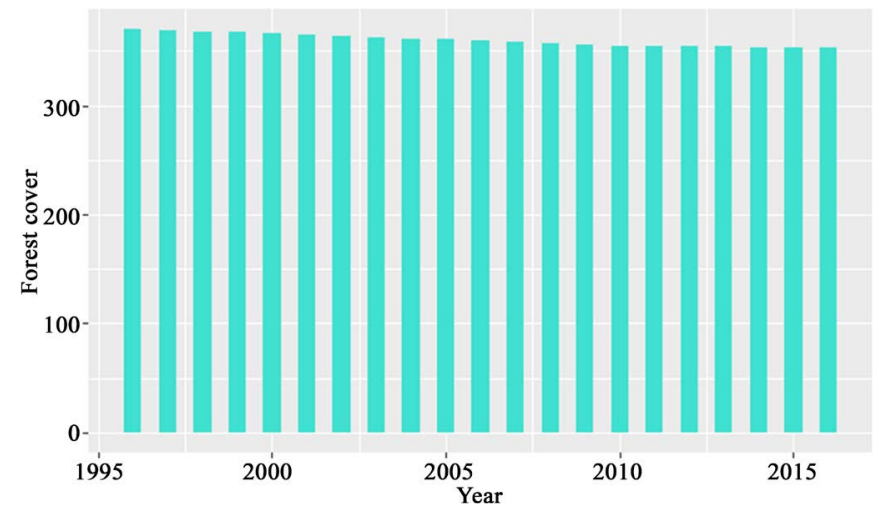

Source: Author, extracted from World Bank WDI data.

Figure 6. Evolution of forest cover (in sq. km).

${ }^{8}$ This is a provision obliging operators, in the case of wood exploitation, to locally process at least $85 \%$ of their production and to export no more than $15 \%$.

${ }^{9}$ In particular carbon dioxide $\left(\mathrm{CO}_{2}\right)$. 


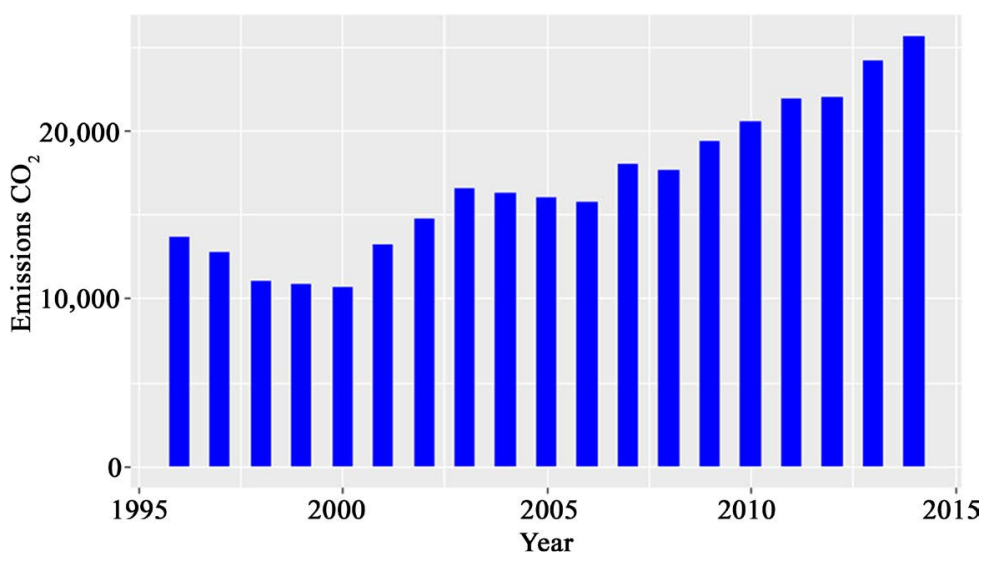

Source: Author, extracted from World Bank WDI data.

Figure 7. Evolution of $\mathrm{CO}_{2}$ emissions (in kt).

These two Figures highlight the effects of the intense forestry sector activity in the Congo Basin from 1996 to 2014. The embryonic nature of the forest industry means that the bulk of production is exported. The influx of FDI in this sector is partly responsible for deforestation, the salient manifestations of which are the decrease in forest cover and the increase in $\mathrm{CO}_{2}$ emissions. Thus, there was a downward trend in forest cover in the Congo Basin during the period under review. $\mathrm{CO}_{2}$ emissions, with the exception of a drop during the 1996-2000 and 2004-2006 periods, have been increasing continuously since 2001. If these trends continue, it raises questions about the capacity of the Congo Basin to ensure its role as a regulator of the global climate alongside the Amazon.

\section{Conclusion and Policy Implications}

Sustainable development and the mobilization of external capital remain the leitmotif of all economic policy actions in developing countries characterized by low domestic savings. Thus, and particularly for African countries endowed with natural resources, strategies (such as the adoption of attractive mining and forestry codes) have been implemented with a view to attracting external financing in general and FDI in particular. The objective of this paper is to analyze the effects of forest resources on the reception of foreign direct investment in the countries of the Congo Basin.

The panel data used cover the period 1996-2018 and are extracted from the World Bank's WDI and WGI databases. The spatial autocorrelation of FDI inflows into the Congo Basin leads to the use of a spatial dynamic Durbin model (SDM). The results of the estimation of this model by the maximum likelihood method show that forest resources have a significant positive effect on FDI inflows and that the spillover effects of inflows from the neighborhood $(\rho)$ are also positive and significant. These results imply a need for 1) the generalization of logging in forest concessions while encouraging their certification and 2) the subregional harmonization of a repressive mechanism in cases where the legal 
and regulatory texts regarding logging are violated. The limit of this work is the exogeneity of the weight matrix. Thus, the use of an endogenous weight matrix is an avenue to be explored later.

\section{Conflicts of Interest}

The author declares no conflicts of interest regarding the publication of this paper.

\section{References}

Anyanwu, J. (2012). Why Does Foreign Direct Investment Go Where It Goes? New Evidence from African Countries. Annals of Economics and Finance, 13, 425-462.

Asiedu, E. (2002). On the Determinants of Foreign Direct Investment to Developing Countries: Is Africa Different? World Development, 30, 107-119.

https://doi.org/10.1016/S0305-750X(01)00100-0

Asiedu, E. (2006). Foreign Direct Investment in Africa: The Role of Natural Resources, Market Size, Government Policy, Institutions and Political Instability. The World Economy, 29, 63-77. https://doi.org/10.1111/j.1467-9701.2006.00758.x

Asiedu, E. (2013). Foreign Direct Investment, Natural Resources and Institutions. London: International Growth Center.

Asiedu, E., \& Lien, D. (2003). Capital Controls and Foreign Direct Investment. World Development, 32, 479-490. https://doi.org/10.2139/ssrn.416722

Asiedu, E., \& Lien, D. (2011). Democracy, Foreign Direct Investment and Natural Resources. Journal of International Economics, 84, 99-111. https://doi.org/10.1016/j.jinteco.2010.12.001

Auty, M. (2001). The Political Economy of Resource-Led Growth. European Economic Review, 45, 839-846. https://doi.org/10.1016/S0014-2921(01)00126-X

Auty, R., \& Warhurst, A. (1993). Sustainable Development in Mineral Exporting Economies. Resources Policy, 19, 14-29. https://doi.org/10.1016/0301-4207(93)90049-S

Beblawi, H. (1987). The Rentier State in the Arab World. Arab Studies Quarterly, 9, 383-398.

Botlhole, T., Asafu-Adjaye, J. O. H. N., \& Carmignani, F. (2012). Natural Resource Abundance, Institutions and Tax Revenue Mobilisation in Sub-Sahara Africa. South African Journal of Economics, 80, 135-156. https://doi.org/10.1111/j.1813-6982.2011.01305.x

Caselli, F., \& Tesei, A. (2016). Resource Windfalls, Political Regimes, and Political Stability. Review of Economics and Statistics, 98, 573-590. https://doi.org/10.1162/REST a 00538

Cleeve, E. A., Denrah, Y., \& Yiheyis, Z. (2015). Human Capital and FDI Inflows: An Assessment of the African Case. World Development, 74, 1-14. https://doi.org/10.1016/j.worlddev.2015.04.003

Coase, R. H. (1988). The Nature of the Firm: Meaning. Journal of Law, Economics, \& Organization, 4, 19-32.

Collier, P., \& Hoeffler, A. (1998). On Economic Causes of Civil War. Oxford Economic Papers, 50, 563-573. https://doi.org/10.1093/oep/50.4.563

Collier, P., \& Hoeffler, A. (2002). On the Incidence of Civil War in Africa. Journal of Conflict Resolution, 46, 13-28. https://doi.org/10.1177/0022002702046001002 
Collier, P., Hoeffler, A., \& Rohner, D. (2009). Beyond Greed and Grievance: Feasibility and Civil War. Oxford Economic Papers, 61, 1-27. https://doi.org/10.1093/oep/gpn029

Corden, W. M., \& Neary, J. P. (1982). Booming Sector and Deindustrialisation in a Small Open Economy. The Economic Journal, 92, 825-848. https://doi.org/10.2307/2232670

De Soysa, I. (2002). Paradise Is a Bazaar? Greed, Creed, and Governance in Civil War, 1989-99. Journal of Peace Research, 39, 395-416. https://doi.org/10.1177/0022343302039004002

Dunning, J. (1979). Explaining Changing Patterns of International Production: In Defense of the Eclectic Approach. Oxford Bulletin of Economics and Statistics, 41, 269-285. https://doi.org/10.1111/j.1468-0084.1979.mp41004003.x

Dunning, J. (1993). Internationalizing Porter's Diamond. Management International Review, 33, 7-15.

Dunning, J. H. (1988). The Investment Development Cycle and Third World Multinationals. Transnational Corporations and Economic Development, 3, 135-166.

Elhorst, J. P. (2010). Applied Spatial Econometrics: Raising the Bar. Spatial Economic Analysis, 5, 9-28. https://doi.org/10.1080/17421770903541772

Fearon, J. D. (2005). Primary Commodity Exports and Civil War. Journal of Conflict Resolution, 49, 483-507. https://doi.org/10.1177/0022002705277544

Gylfason, T., \& Zoega, G. (2006). Natural Resources and Economic Growth: The Role of Investment. The World Economy, 29, 1091-1115. https://doi.org/10.1111/j.1467-9701.2006.00807.x

Heckscher, E. (1919). The Effect of Foreign Trade on the Distribution of Income. Ekonomisk Tidskrift, 21, 497-512.

Hsiao, C. (1986). Analysis of Panel Data. Econometric Society Monographs, No. 11, Cambridge: Cambridge University Press.

Humphreys, M., Sachs, J. D., Stiglitz, J. E., \& Soros, G. (2007). Escaping the Resource Curse. New York: Columbia University Press.

Jadhav, P. (2012). Determinants of Foreign Direct Investment in BRICS Economies: Analysis of Economic, Institutional and Political Factor. Social and Behavioral Sciences, 37, 5-14. https://doi.org/10.1016/j.sbspro.2012.03.270

Kaldor, M., Martin, M., \& Selchow, S. (2007). Human Security: A New Strategic Narrative for Europe. International Affairs, 83, 273-288. https://doi.org/10.1111/j.1468-2346.2007.00618.x

Karl, T. L. (2007). Ensuring Fairness. In M. Humphreys, J. D. Sachs, \& J. E. Stiglitz (Eds.), Escaping Resource Curse (pp. 256-285). New York: Colombia.

Kaufman, D., Kraay, A., \& Massimo, M. (2012). The Worldwide Governance Indicators (WGI) Project.

Kinda, T. (2010). Increasing Private Capital Flows to Developing Countries: The Role of Physical and Financial Infrastructure in 58 Countries, 1970-2003. Applied Econometrics and International Development, 10, 57-72.

Krugman, P. (1987). The Narrow Moving Band, the Dutch Disease, and the Competitive Consequences of Mrs. Thatcher: Notes on Trade in the Presence of Dynamic Scale Economies. Journal of Development Economics, 27, 41-55. https://doi.org/10.1016/0304-3878(87)90005-8

Krugman, P. (1991). Increasing Returns and Economic Geography. Journal of Political Economy, 99, 483-499. https://doi.org/10.1086/261763

Le Gallo, J. (2004). Space Heterogeneity, Principles and Methods. Economics \& Forecast- 
ing, 162, 151-172. https://doi.org/10.3406/ecop.2004.6939

Mensah, L., \& Asamoah (2015). Foreign Direct Investment and Natural Resources in Africa. Journal of Economic Studies, 42, 608-621. https://doi.org/10.1108/JES-01-2014-0023

Moradbeigi, M., \& Law, S. H. (2016). Growth Volatility and Resource Curse: Does Financial Development Dampen the Oil Shocks? Resources Policy, 48, 97-103. https://doi.org/10.1016/j.resourpol.2016.02.009

Morisset, P. (2000). Foreign Direct Investment to Africa: Policies Also Matter. Transnational Corporation, 9, 107-125.

Mucchielli, J. L. (1991). Strategic Alliances and Multinational Firms: A New Theory for New Forms of Multi-Nationalization. Journal of Industrial Economics, 55, 118-134.

Noorbakhsh, F., Paloni, A., \& Youssef, A. (2001). Human Capital and FDI to Developing Countries: New Empirical Evidence. World Development, 29, 1593-1610. https://doi.org/10.1016/S0305-750X(01)00054-7

Ohlin, B. (1933). Interregional and International Trade. Cambridge, MA: Harvard University Press.

Onyeiwu, S., \& Sherstha, H. (2004). Determinants of Foreign Direct Investment in Africa. Journal of Development Societies, 20, 89-106. https://doi.org/10.1177/0169796X04048305

Papyrakis, E., \& Gerlagh, R. (2004). The Resource Curse Hypothesis and Its Transmission Channels. Journal of Comparative Economics, 32, 181-193. https://doi.org/10.1016/j.jce.2003.11.002

Pedroni, P. (2001). Purchasing Power Parity Tests in Cointegrated Panel. The Review of Economics and Statistics, 83, 727-731. https://doi.org/10.1162/003465301753237803

Poelhekke, S., \& van der Ploeg, F. (2010). Do Natural Resources Attract FDI? Evidence from Non-Stationary Sector-Level Data. CEPR Discussion Paper 8079. https://doi.org/10.2139/ssrn.1950092

Poelhekke, S., \& van der Ploeg, F. (2013). Do Natural Resources Attract Non Resource FDI? Review of Economics and Statistics, 95, 1047-1065. https://doi.org/10.1162/REST a 00292

Robinson, W. I. (2014). Global Capitalism and the Crisis of Humanity. Cambridge: Cambridge University Press. https://doi.org/10.1017/CBO9781107590250

Ross, M. L. (2001). Does Oil Hinder Democracy? World Politics, 53, 325-361. https://doi.org/10.1353/wp.2001.0011

Ross, M. L. (2004). What Do We Know about Natural Resources and Civil War? Journal of Peace Research, 41, 337-356. https://doi.org/10.1177/0022343304043773

Samuelson, P. A. (1948). International Trade and the Equalization of Factor Prices. Economic Journal, 58, 163-184. https://doi.org/10.2307/2225933

Slaibi, A. A., \& Kyle, S. C. (2007). The Macroeconomic Impact of Mineral Revenues on General Market Equilibrium and Poverty Alleviation in Sub-Saharan Africa. The Journal of Energy and Development, 32, 283-310. https://doi.org/10.2139/ssrn.1525553

Soysa, I., \& Neumayer, E. (2007). Resource Richness and the Risk of Civil War: Results from a New Data Set on Natural Resource Rentals, 1970-1999. Conflict Management and Peace Science, 24, 201-218. https://doi.org/10.1080/07388940701468468

Tobler, W. R. (1970). A Computer Movie Simulating Urban Growth in the Detroit Region. Economic Geography, 46, 234-240. https://doi.org/10.2307/143141 
UNCTAD (2019). World Investment Prospect Survey. Geneva: UNCTAD.

Van der Ploeg, F. (2011). Natural Resources: Curse or Blessing? Journal of Economic Literature, 49, 366-420. https://doi.org/10.1257/jel.49.2.366

Vernon, R. (1966). International Investment and International Trade in the Product Cycle. Quarterly Journal of Economics, 80, 190-207. https://doi.org/10.2307/1880689

Wiig, A., \& Kolstad, I. (2010). Multinational Corporations and Host Country Institutions: A Case Study of CSR Activities in Angola. International Trade Review, 19, 178-190. https://doi.org/10.1016/j.ibusrev.2009.11.006

World Bank (2019). World Development Indicators (WDI).

Wright, J., Frantz, E., \& Geddes, B. (2015). Oil and Autocratic Regime Survival. British Journal of Political Science, 45, 287-306.

https://doi.org/10.1017/S0007123413000252 


\section{Appendices}

\section{A1. Weight Matrix Used}

\begin{tabular}{l|rrrrr}
\multicolumn{1}{c}{1} & 2 & 3 & 4 & 5 \\
\cline { 2 - 6 } 1 & 0 & .1301040524 & .1329068073 & .0640824786 & .5433247515 \\
2 & .1242221475 & 0 & .1382004978 & .0724876645 & .5300637734 \\
3 & .1255542337 & .1367368387 & 0 & .0743676623 & .52709767 \\
4 & .0818147005 & .0969277077 & .100506011 & 0 & .6244904971 \\
5 & .2012140415 & .2055979165 & .2066358895 & .1811476002 & 0 \\
6 & .1239708236 & .1352957126 & .1379771175 & .0721329697 & .5306233767 \\
\hline
\end{tabular}

6

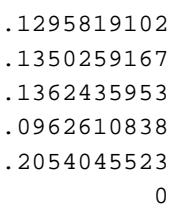

\section{A2. Post Estimation}

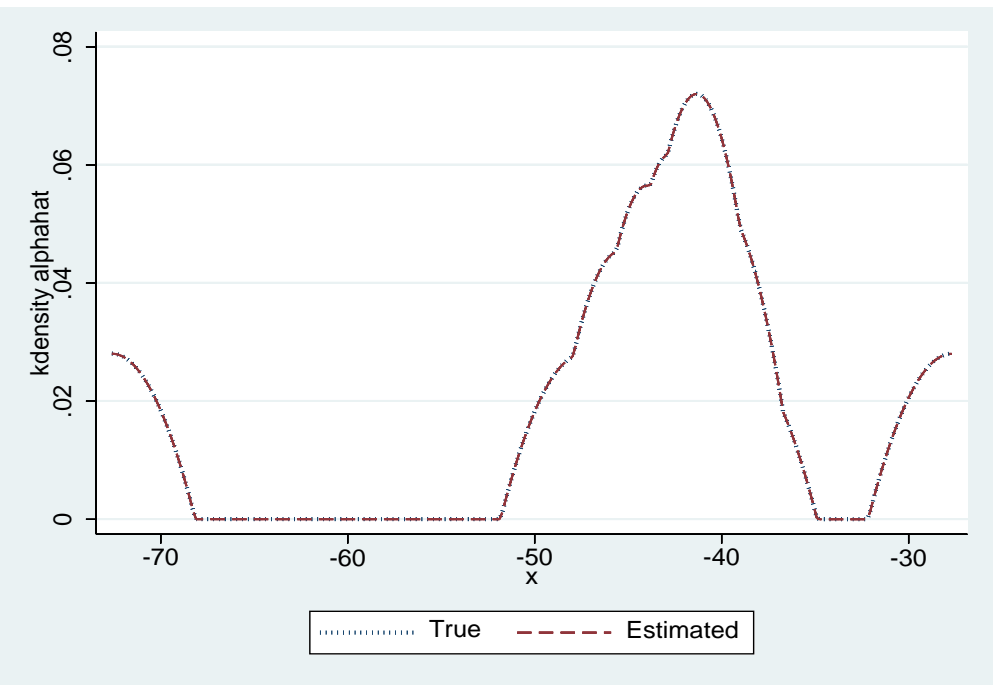

